\title{
Beyond the State: Global Policy and Transnational Administration
}

\section{Kim Moloney and Diane Stone}

\section{(2) OpenEdition}

\section{Journals}

Electronic version

URL: http://journals.openedition.org/irpp/344

DOI: $10.4000 /$ irpp.344

ISSN: 2706-6274

Publisher

International Public Policy Association

\section{Printed version}

Date of publication: 17 June 2019

Number of pages: 104-118

ISSN: 2679-3873

\section{Electronic reference}

Kim Moloney and Diane Stone, «Beyond the State: Global Policy and Transnational Administration », International Review of Public Policy [Online], 1:1 | 2019, Online since 17 June 2019, connection on 04 October 2019. URL : http://journals.openedition.org/irpp/344 ; DOI : 10.4000/irpp.344

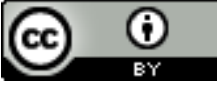




\section{Beyond the State: Global Policy and Transnational Administration}

\section{Kim Moloney}

Senior Lecturer in Public Administration and Policy, Murdoch University

\section{Diane Stone}

Dean-elect School of Public Policy, Central European University, Hungary and Professor, Institute for Governance and Policy Analysis, University of Canberra, Australia, and Professor of Politics and International Studies, University of Warwick, UK

\section{Abstract}

The conceptual distance between the sovereign state and the global domain of policy making and administration is narrowing, challenging the prevailing methodological nationalism. The rise of global policy and transnational administration necessitates new conversations for traditional, often domestically focused, public policy and public administration studies. By expanding our analytical, theoretical, conceptual, and even our pedagogical approaches to include the kaleidoscope of global governance actors, levels of analysis, sectors, and concepts, not only is our policy research enhanced and deepened, but our ability to engage this complexity is enhanced.

\section{Keywords}

global policy, public policy, public administration, transnational administration 


\section{Introduction}

Traditionally, studies of public administration and public policy have treated the nation-state as the unit of analysis. That is, state agencies and policies, or its sub-national units, are examined. Alternatively, the sovereign public administrations of states are compared. This is known as 'methodological nationalism' (Stone and Ladi, 2015; Bauer et al, 2018). However, the state does not exist in a vacuum wholly distinct from other states or from international organizations (IOs). Moreover, neither do citizens, businesses, and civil society, nor do the transnational bodies that emerge from these communities. Indeed, each aspect is occasionally incorporated or co-opted into global governance activities. There is clear evidence of the rise of many different modes of 'global policy and transnational administration' (GP\&TA) but as we have argued elsewhere (see the Introduction to Stone and Moloney, 2019), mainstream policy studies and especially public administration has been slow to adapt to the new realities.

This paper proceeds by examining the key terms of transnational administration and global policy studies before evaluating the state of this growing school in public administration and policy studies. The second section considers the scholarly spaces where we can locate teaching and advance research of GP\&TA such as through use of case studies or consideration of the publishing and professional arenas of GP\&TA. We conclude with a few caveats and cautions such as a dominance (and contestation) of Western-centric conceptualizations of 'global policy' and 'transnational administration'.

\section{Going Global in Policy Studies and Public Administration}

Typical public policy and public administration studies focus on the state, its agencies, its subnational interactions, and the actors and processes influencing national policy creation and its administration. In general, such studies do not ignore the role of the state in the global order but they are prone to overlooking that neither policy nor its administration are exclusively state domains. Globalization, the cross-national interaction of non-state actors sometimes in support of and at other times at odds with state priorities, the creation of IOs, the multiplicity of treaties, and the oft-rapid movement of aspects of daily life from labor and capital to diseases and pollution, helps rupture prior assumptions of hard boundaries setting the state, its policy and administration, apart from transnational arenas.

The porousness of state boundaries and, by extension, a weakened or at least re-configured administrative sovereignty has decentralized and delegated policy and its administration to multiple global governance actors. With the state unable to claim exclusive domains to create policy and administer, one result is a rise in global policy and its transnational administration. This is more extensive than merely an 'internationalized' policy of states such as might occur through policy transfer or 'trans-governmentalism' (Legrand, 2019). The decentralization of policy from the state to global or regional governance is accompanied by the state's concurrent delegation of some of its duties to non-state actors, IOs, and semi-private policy networks. In this multi-actor realm, we do not use the term 'global public policy', not only because the state is no longer the only progenitor of policy and its administration, but also because policy and its administration are no longer products of exclusively public action.

It is the case that already significant works on 'global policy' exist. A number of monographs on the subject have been published, but their number can be counted on two hands. Instead, the study of 'global policy' has been fractured into a policy sector focus with titles such as 'global health policy' or 'global climate policy'. While these sector specific studies are valuable in their own right, the development of an umbrella idea of 'global (public) policy' that speaks to all do- 
mains of policy has not spread beyond a small group of scholars (inter alia, Bauer and Trondal, 2015; Deacon, 2007; Hale and Held, 2011; Knill et al, 2017; Stone and Ladi, 2015; the contributors in Stone and Moloney 2019). For example, the great irony of the 2019 symposium 'On the Future of the Public Policy School' in the journal Global Policy is that none of the contributors interrogate (let alone mention) the category of 'global policy' as either a concept or a practice. To be fair, one contributor notes that policy schools "should be contributing to thorough-going critiques of the global regimes that govern our lives" (Anderson, 2019: 85) and another mentions a world increasingly shaped by globalization (Xue, 2019: 102) but these considerations do not extend to consideration of the administrative domains of IOs or transnational policy networks.

This paucity of scholarship is far more pronounced with regards to the idea of 'transnational administration'. As a google scholar search will reveal, the term rarely appears before 2015 . While public administration has a strong scholarly legacy of comparative studies, especially in development administration, mainstream public administration scholarship infrequently looks beyond national borders to ask whether its core concepts and theories may add value to the study of global governance. Many American and/or US-based public administration scholars use a non-specific 'international' term for any study not focused on the United States. One recent example is the 2018 mini-Minnowbrook conference. This conference, held every twenty years since 1968 , chose to mark its $50^{\text {th }}$ anniversary with a mini-conference. One question asked of invited participants (all but one was based at US universities) was how to make public administration 'more international'. More troubling, was that only two of the invited 38 conference concept papers directly answered this question (Minnowbrook at 50 Concept Papers, 2018).

Yet, GP\&TA has much to offer the study of public administration in matters as diverse as the new human resource management issues presented by the rapid growth of 'transgovernmental networks' (see Alexander Gaus in Stone and Moloney, 2019), the bureaucratic structures of 'global public-private partnerships' (Andonova, 2017) or the financial accountability of 'multidonor trust funds' based in IOs. Instead, legal scholars have partially stolen the march by articulating new thinking around 'global administrative law" (Kingsbury et al, 2005; Ming-Sung Kuo in Stone and Moloney, 2019).

We acknowledge significant efforts to diversify Masters of Public Administration (MPA) and Masters of Public Policy (MPP) curricula to consider the bureaucratic traditions and policy challenges confronted in multiple sovereign states (e.g. Hou, et al 2011; Manoharan, et al 2018; $\mathrm{Wu}$ and $\mathrm{He}$, 2009). Even if a deeply comparative administrative and policy curricula (and its associated scholarship) is made a priority, its base assumption nevertheless often remains: the analytical unit of the state is administration and policy's most important actor.

For this Forum, our paper has a different focus. We agree that the state is a key analytical unit. Indeed, the growth of trans-governmental networks may be a sovereignty enhancing exercise of governmental officials, judges and regulators collaborating with counterparts in other countries on matters as diverse as cyber-security, the adoption of foreign children or banking matters (Legrand, 2019). However, we assert that globalization creates new spaces for policymaking beyond the nation-state. In these spaces of global policy and transnational administration, policy actors influence not only global and regional policies, treaties, and behaviors but, perhaps as importantly, they influence the administrative and policy possibilities within sovereign states. As noted elsewhere by European colleagues, "administrative internationalization is not something that happens elsewhere but rather a transformative force that redistributes 
power and transforms actor relationships in domestic settings and configurations" (Bauer et al, 2018: 16). By reorienting studies to consider global policy and transnational administration, scholars and students of public policy and administration are forced to question whether the state is the most important policy and administrative actor versus other actors such as IOs, Non-Governmental Organizations (NGOs), businesses, and other private-public partnerships. In certain circumstances, each may have greater influence than the state over administrative and policy life.

Alongside traditional IOs, there is now an array of informal IOs, such as the Group of Twenty (G20) and the BRICs, each of which creates its own administrative structure, procedures, and culture (Vabulas, 2019). Likewise, new administrative structures emerge within formal coalitions of various actors (be they international civil servants within an IO, or civil society, corporate and state actors) to deliver policy. New institutional architectures include global public-private partnerships such as the Global Gas Flaring Reduction Initiative (Stone and Ladi, 2015) or, in the field of vaccines and immunization, GAVI (Andonova, 2017), operating semi-autonomously from both states and IOs in their problem specific domain of activity. Each has a bureaucratic body with secretariats administering funding flows, disseminating policy guidelines and monitoring compliance or implementation. Transnational administration can also arise from connected citizenries or corporate communities capable of crossing borders to influence, or at least inform, state behaviors. For instance, the World Economic Forum's influence on global market priorities is notable (Garsten and Sörbom, 2018). There are also private regimes for standard setting like the International Standardization Organization as well as transnational private regulation, or the 'soft law' created by certification schemes in forestry or food (Hale and Held, 2011).

Yet, definitions of GP\&TA are in short supply. The term 'international public administration' has emerged from European Union studies to focus analysis on the secretariats of IOs such as the European Commission (Bauer, Knill, Eckhard, 2017; Bauer and Trondal, 2015). Since the early 1950s, comparative public administration has traditionally referred to studies of two or more administrative states and societies while development administration focuses on the administrative challenges of developing states and their societies. In contrast, international public administration (IPA) (despite frequent American misuse of the term) refers to administrative studies focused on IO secretariats, including comparative studies of them. In our view, this makes IPA a distinct category of public administration where IPA incorporates international administrations such as to be found in IOs or in arrangements between governments and IOs. By contrast, 'transnational administration' not only encroaches upon the IPA of intergovernmental relations and IOs but is a separate category that incorporates the administrative structures and practices of transnational policy networks and global public-private partnerships as well as that of private regulatory regimes.

The idea of global public policy as "governing without government" (Reinicke 1998) is too truncated and does not capture how GP\&TA is made up of dynamic and complex spaces that are part private and quasi-public. Stone and Ladi (2015: 2) have provided two linked definitions:

Global (Public) Policy (GPP) refers to a set of overlapping but disjointed processes of public-private deliberation and cooperation among both official state-based and international organizations and non-state actors around establishing common norms and policy agendas for securing the delivery of global public goods or ameliorating transnational problems. [...]

Transnational Administration (TA) refers to the regulation, management and implementation of global policies of a public nature by both private and public actors. 
It should be noted that definitions of 'GPP' and of 'transnational' or 'international administration' are new, evolving, and in need of critical engagement. Some may bridle at this point and consider that the definitions above are little different from some contemporary understandings found in the study of international relations (IR) or international political economy (IPE). But by taking this terminology, we wish to prioritize the concepts and frameworks of policy studies and public administration, and to suggest that different sets of questions are asked compared to other disciplines.

The removal of 'public' from global (public) policy acknowledges that not all regional and global policies are created exclusively by and for states. Instead, private actors are deeply imbricated in transnational policy design, implementation and policy monitoring. The term 'transnational' administration suggests that while comparative and development-focused administrative and policy studies are important, an exclusive focus on such state-led acts aligns scholars to a methodological nationalism that is no longer as relevant today as it was some forty years ago.

By using the double-definition above as our frame we do not intend to conflate 'global policy' with 'transnational administration'. It is the case that public administration is treated as a distinct discipline in North American contexts with its own conferences, professional associations and curricula. However, we cannot do more than note here the grey areas between fields of study and suggest that the fine-grained distinctions that are made between 'public administration', 'public sector management' and 'public policy' (eg Hur and Hackbart, 2009) are not only being whittled away by the forces of globalization but, more to the point, such distinctions are the subject of another contribution to the Forum. Instead, our preference is to advocate the benefits of 'disciplinary trespass' (Hirschman, 1981) and to borrow from other fields of study (Szostak, 2005) - like global administrative law (Kingsbury, 2005) or global social policy (Artaraz and Hill, 2016; Deacon, 2007) as well as IR and IPE (Higgott and Woo in Stone and Moloney, 2019) - that also have very much to say about policy making by transnational actors and the administrators of global governance.

\section{The Global Public Sphere and Global Citizens}

Interdisciplinarity is most evident in scholarly thinking on the 'global' or 'transnational public sphere', which draws as much from sociology and philosophy as it does from IPE and IR. Public spheres outside the Westphalian framework of state sovereignty are to be found at regional or micro-regional level, at the global level, in cross-national communities or as virtual spaces. An amorphous idea, some see this sphere as a discursive arena that overflows the bounds of both states and nations, as network relations or as communicative venues that may hold potential as alternative democratic spaces (Norman, 2017).

The idea of a global public sphere comes on the heels of a disparate literature on global citizenship and global citizenship education (Goren and Yemini, 2017). The civil servant is responsible to the state's balance of powers and to citizens served by the state. The served citizens are often legally defined as persons with "the right to participate in government and public life" (the legal definition) but also an "obligation to participate" (Cooper \& Yoder, 1999: 196, emphasis in original). However, and when applied to the global space, neither the legal nor the 'right' or 'obligation' definitions have neat parallels. Not only is there no legally binding definition of 'global citizen' but there is also no individual right or obligation to participate.

This distance between citizens and other participatory spaces may be both long and highly indirect (e.g. between state citizens and the UN General Assembly, participation is indirect through their state's Ambassador to the United Nations) or short and direct (e.g. the \#metoo 
social movement across borders). The direct and clear boundaries within Westphalian states for citizens to engage in participatory acts is no longer the only space for such participation. One result is that the legal definitions common to citizenship do not exist for 'global citizens'.

For scholars of public policy and public administration who are used to placing the citizen as one center of state-bounded analysis, the insufficient global parallel poses a problem if, as in state-level citizenship considerations, it is the "ethical dimension of citizenship that provides the normative foundations for the role of the public administrator" (Cooper and Yoder, 1999: 196). It may be that, as Turner (1993: 178) asserted, "the nation-state is not necessarily the most suitable political framework for housing citizenship rights". This is particularly true in countries where direct individual appeals to supranational judicial bodies for adjudication are allowable (e.g. European Court of Justice, African Court on Human and Peoples' Rights) and where individuals may be prosecuted by supranational judicial bodies (e.g. International Criminal Court).

If the state no longer offers significantly fulsome opportunities for citizens to evaluate policy and administrative life, then (global or regional) citizenship and the education of those citizens becomes particularly problematic (Davies, 2006). The resulting rise of transnational actors with influence across states that runs deep within jurisdictional levels puts pressure not only on universities to prepare students for this complex global arena but also stimulates the policy studies and public administration professions to reconsider its assumptions. The encouragement by governments and IOs to prepare students for the global world of work is not a new endeavor. Within the professional academic associations of public policy and public administration communities, there have been efforts to encourage a globally prepared policymaker and administrator with MPA/MPP programs ( $\mathrm{Pal}$ and Clark, 2016), which we discuss in one of the sub-sections below.

\section{Scholarly Spaces for Global Policy and Transnational Administration}

This section engages four scholarly spaces for consideration of global policy and transnational administration: (i) teaching, (ii) problems and case study analysis (by governance level, actor, sector, and concept), (iii) publishing, and (iv) the profession. There can be additional ways to categorize scholarly practice, but given word constraints we limit discussion to some obvious domains:

\section{Teaching}

One indicator of the rise of GP\&TA is the extent to which there are distinct teaching programs in this field. There is evidence that universities are adapting the curricula for young professionals who must increasingly traverse transnational policy processes. As expanding globalized institutions of science and expertise, universities, their scholars and their students are drawn into, and help constitute, these global spaces of policy and administration.

Scholars are not totally detached observers, and students are not passive recipients of their education; instead, both are important mediators in global dynamics (Gallagher et al, 2016: 442). Learning and pedagogy can be experiential and shape scholarship just as scholarship may influence learning. Examples of student and faculty involvement in global issues include famine relief (late 1980s), anti-apartheid and sanctions (1980s to early 1990s), protests against neoliberal IOs like the World Bank, the International Monetary Fund (IMF), and the World Trade Organization (1990s to early 2000s), sweatshop activism (2000s) and, recently, movements aided by social media such as the \#metoo hashtag (2010s). Each have become loci of 
both scholarship and activism within and external to policy and administrative studies.

Despite recent empirical work on the dearth of comparative and development administrative teaching in countries as diverse as the United States, Ghana, and China (see Haruna and Kannae, 2013; Manoharan et al, 2017; Wu and He, 2009 respectively), there is as yet no empirical work on the prevalence of global policy and transnational administration curricula. We suggest that methodological nationalism infuses not only academic worldviews but is also institutionalized in national (social) science funding institutions that may prioritize national interests and state-focused syllabi. Similarly, faculty recruitment and hiring patterns in national higher education systems are often geared to servicing local and national communities and professions. Each reason cannot be separated from broader observations about disciplinary boundaries, budget allocations, and how degree options are presented to students. These organizational principles and the 'newness' of GP\&TA to administrative and policy studies (as opposed to IPE or IR) have made empirical work especially difficult and allows us to remark only on recent observable trends.

Graduate programs in 'global public policy' were rare in the 1990s but were burgeoning by the second decade of the twenty-first century. Illustrative examples include the Masters in Global Policy at Boston University, Queen Mary College, and the Pardee School of Global Studies, or in another instance, that of University College London's delivering a Master of Science in International Policy that "brings together the academic study of international relations with analysis of public policy formulation and governance beyond the nation-state". Seemingly related at first glance, the OECD has established a Global Network of Schools of Government to strengthen "the link between international policy dialogue and national efforts to build capabilities in the public sector" (Pal and Clark, 2016: 287, citing OECD, 2017). Despite its name, this Network supports national systems of public sector education.

Dual degree programs have also flourished. Of particular relevance is the Global Public Policy Network (GPPN), a consortium of seven public policy schools from around the world that operates as a platform for research collaboration and student exchange. Network partners proclaim that they adopt a "strong global orientation that recognizes the ways in which policymaking crosses national boundaries and is shaped by an increasingly interconnected and interdependent world" (GPPN, n.d.). However, one review of MPA and MPP programs delivering GP\&TA curriculum content found that national accreditation systems influence course offerings and that, at least in the United States, many programs lack explicit curriculum development to encourage globally oriented graduates (Jeong and Kim, 2019). Notwithstanding a rise in universities with global research partnerships, joint degrees and branch campuses, such cross-national institutional links do not necessarily translate into revised or globalised curricula content.

\section{Problem Cases}

Case studies are an important research method and pedagogical tool for expanding beyond state-focused administrative and policy studies and "can be useful in promoting problem-based learning” (Bushouse, et al., 2011: i106; Szostak, 2005; Volpe, 2015; Walker, 2009). This is important in a complex and fast-changing world in which transnational administration and global public policy co-exist with local problems and national administrations where some policy sectors are more globalized than others. However, as noted earlier, the limitation of case-based approaches to GP\&TA is that they encourage a fracturing of research to specific policy sectors and policy problems. Case study approaches can be explored by governance level, by actor, by sector, and by concept. 
Governance Level: Identifying levels of governance is a seemingly simple exercise in studies beholden to methodological nationalism but becomes a more complex exercise in GP\&TA. This may include discussions of whether the 'inside/outside' dichotomy exists, if boundaries are porous, and where boundaries vary by sector. Climate change is a particularly important arena for questioning these scales of governance and to ask if states should be primarily responsible for problems that are ultimately collective in nature. Another approach is via multilevel governance studies. While such studies are largely driven by EU scholarship, a GP\&TA approach might ask if EU models are (or should be) exported to other regions. Such discussions may engage questions of polycentric governance across fixed jurisdictions (Andersson and Ostrom, 2008). This includes studies of the city as an actor with potential relevance to global policy making; for instance, studies focused on international networks of cities (e.g. ICLEI - Local Governments for Sustainability), a city's para-diplomatic potential or even the independent regulatory initiatives of cities in global climate change (Betsill and Bulkeley, 2006).

Actors: States and IOs are complemented by business and civil society and a multiplicity of neworks and alliances for making global policies and transnationally administering their implementation. Each may be an independent variable in certain instances while in others the actor is the dependent variable. The state can be an actor with power to influence global policy and transnational administration (as an independent variable) as well as an actor influenced by such policies and administrative practices (as the dependent variable). This includes how the administrative state is altered by the processes of globalization and the state's part in the co-creation of global governance such as through trans-governmental networks. Although "globalization does not end the state and public administration," (Farazmand, 1999: 519) it does pose challenges: perceived threats to sovereignty, questions about the empowerment of a global elite and increased inequality (Anderson, 2019; Piketty, 2014), but also whether transnational administration encourages or discourages democratic progress (Farazmand, 1999). Looking at how global hegemons might disproportionately influence the IOs that then influence states extends to a world in which sub-regional and regional organizations considerably outnumber IOs is also pertinent here. In such cases, hegemony might include the influence of Trinidad and Tobago along with Jamaica over the Caribbean Community (CARICOM), the dominance of South Africa within the Southern African Customs Union, or that of Brazil within the Corporacion Andina de Fomento - Banco de Desarrollo de América Latina.

Despite a scholarly tendency to focus on international bodies with either the largest number of member-states and greatest global importance and/or where scholarship is most likely to exist (e.g. United Nations, World Bank, International Monetary Fund, World Health Organization, World Trade Organization), opportunities are missed when the diversity of IOs is excluded. This includes the growing importance of informal IOs (without a formal secretariat) who also create global policy and transnationally administrate global actions. The G20 is most notable but other examples include the Eurogroup of Finance Ministers, the Clean Energy Ministerial, or the Mission Technology Control Regime (Vabulas, 2019). Corresponding to such groups is a growing galaxy of semi-public or part-private global partnerships and networks. GAVI, a partnership initiated by the Gates Foundation in conjunction with pharmaceutical companies and developing country governments, is one of the best known. These tri-partite entities are particularly evident in the global health or global environment policy sectors (Andonova, 2017). They deliver public services (not necessarily efficiently or effectively) and the funding that flows to these partnerships also generates administrative structures (see Arianne Wessal and Clay Wescott in Stone and Moloney, 2019). 
Global civil society also requires inclusion in any GP\&TA discussion. Civil society is an independent variable that influences the GP\&TA carried out by states and IOs; for instance, NGO interaction - often critical - within World Bank operations (Kerler, 2007). Civil society may also be the dependent variable: for example, the influence of the North Korean state on foreign NGO activity during its late 1990s famine (Flake and Snyder, 2003). Other actors include think-tanks, business associations, and philanthropic foundations - entities that are increasingly global or regional in their activities - including International Federation of Red Cross and Red Crescent Societies (NGO), Bangladesh Rice Research Institute (think tank), African Women Development Fund (foundation), as well as corporate associations like the Corporate Council on Africa, or multinational corporations like Digicel providing technical and reconstruction assistance in post-earthquake Haiti. The federated or multi-national structure of large civil society bodies (e.g. Transparency International, Oxfam, Gates Foundation) suggests that they too can be treated as 'transnational administrations' in their own right.

Sector: There are sector-focused IOs on a diverse range of topics, such as oil-producing states (Organization of the Petroleum Exporting Countries), coconuts (Asian and Pacific Coconut Community), or policing (Interpol). Policy issues and problems can be unique to a sector - such as the specific administrative law and phyto-sanitary standards of IOs in global food production and regulation. At other times, there are universal concerns of effectiveness, efficiency and equity across sectors - this might include accountability challenges concerning internet domains and ICANN (Koppell, 2005) or (lack of) state compliance implementing commitments towards global endangered species (Gehring and Ruffing, 2009). The point is that the issue, or problem, or content of global policy, affects the character of transnational administration - the specific rules and procedures, budgeting and reporting, and the transparency and conduct of administrative officials who work in IOs or increasingly, working in partnership with private organizations.

Concept: There are at least two conceptual categories available. The first approach draws directly on established public policy and public administration concepts 'scaled-up' to explore their global governance applications. This includes addressing personnel management within IOs, questions of ethics and whistleblowing, budget transparency, and internal reform (Moloney and Stoycheva, 2018). It may also comprise ideas taught in public policy such as the policy cycle heuristic or the 'policy design' approach as well as how concepts of 'policy entrepreneurialism,' 'bureau-shaping' or 'policy community' can be 'stretched' (Stone and Ladi, 2015) beyond their nation-state origins to analyze regional and global dynamics. Where caution must be observed, it is not to assume that concepts applicable to the domestic spaces may be applied without alteration in global arenas. This is illustrated in tasks as simple as considering where institutional characteristics between judicial institutions at the national-level and those at the supranational level may differ and, perhaps as importantly, how such differences alter our understanding of typical policy and administration concepts.

The second category is concepts or even slogans with local and global appeal. This includes the much-criticized notion of 'global citizenship' (Dower and Williams, 2016). Engagement with this idea may entail consideration of whether water is a human right, or about climate change refugees, and if we have a 'Responsibility to Protect', but also the practical implications of how to deliver and administer each concern. Each issue impinges upon citizenship questions, an 'othering', and ways of comprehending global collective responsibilities (Davies, 2006). Similar contestable concepts already in circulation include campaigns such as 'act local, think global' or those encouraging citizens to buy nationally produced goods (and implicitly discourage foreign 
trade). Each concept has policy and administrative consequences and the potential to generate new literatures on the jurisdictional level in which policy change could be located and which actors should be responsible for its implementation.

\section{Publishing}

Any discussion of GP\&TA in relation to its cousins in domestic policy and administrative studies cannot be far removed from where scholars might publish their work. This is an important question given the state's dominance as the scholar's key unit of analysis. Journals underpinned by unconscious understandings of methodological nationalism may unintentionally limit GP\&TA opportunities. In other circumstances, editorial judgements might consider that the subject matter of GP\&TA be reserved for, or relegated to, journals in IR and IPE.

However, the tide is changing. Since the mid-1990s, a number of academic journals have come into existence. Global Governance: A Review Multilateralism and International Organisation was one of the first, in 1995, followed by Global Networks and Global Social Policy (both in 2001), and Global Policy in 2010. The latest is Global Constitutionalism created in 2012 and Global Summitry launched in 2015. They complement established outlets such as International Review of Administrative Sciences (IRAS) and Public Administration, and especially Regulation and Governance, all of which address supranational policy and administration beyond state structures. The International Review of Public Policy, the journal in which this paper is published, will also face its own crossroads as to whether its emphasis will follow state-driven comparative and international policy and administrative analyses or whether it will consider that the international review' in its name to include the global policy and transnational administration space. A recent meta-review of 47 public administration journals has already lamented the scant attention given to what the authors call 'administrative internationalization' and how public administration scholarship remains "a prisoner of the word 'state" (Bauer et al, 2018: 15).

Textbooks focused specifically on GP\&TA are yet to emerge. Usually, textbooks on public policy and administration devote at least a chapter or two to 'globalization' (see, inter alia, Kennett, 2008; Moran et al, 2006). Unsurprisingly, such textbooks put government at the center of analysis, and when globalization is considered, it is often in terms of pressures upon the state and subsequent state responses, rather than how global governance architectures represent analytically distinct sites for policy analysis. Methodological nationalism remains entrenched in curricula, in the national structure of most policy studies professional associations and in the contents pages of public administration textbooks.

Edited volumes and Handbooks can provide concise commentaries on the identity of public administration and policy studies. This includes compilations that view globalization and public administration's engagement of non-sovereign administrative interests as a subsidiary concern (see, inter alia, Menzel and White 2011). There are also compilations where global policy and/or transnational administration are the primary concern. This includes the authors of this paper's edited Oxford Handbook on Global Policy and Transnational Administration (Stone and Moloney, 2019) or the excellent IPA-specific engagements with the discipline of public administration (Bauer, Knill, and Eckhard 2017).

More generally, it is difficult to ignore the 'elephant in the room' that is the dominance of the English language as the main medium of knowledge exchange. In many policy fields - such as international aviation - English is the working language. Accordingly, English becomes an 'everyday' signifier of GP\&TA and the power disparities that lie within. This extends to locations of academic hiring and preferences, in parts of Asia at least, for terminal degrees from 
Western universities (Moloney, 2018) and is particularly pronounced in public administration (Drechsler, 2013). Claims of neo- and/or cultural imperialism emerge with the marginalization of indigenous language groups; the hegemonic dominance of English in scientific publications and, to a lesser extent today than in the past, the cultural industries. The extent to which social media and other internet platforms in other languages might break the inequities inherent to 'global English' dominance remains moot.

\section{The Profession}

Any expansion of GP\&TA studies is likely to find great opportunities through direct engagement with the policy and administrative professional communities in addition to academic associations. Prospects for exchanges or secondments with IOs, international NGOs and other transnational actors have increased in tandem with greater pressures from governments on universities to demonstrate their social and economic value through 'impact' (Legrand and Stone, 2018). Universities and associational groups (such as the International Public Policy Association - IPPA) can not only provide important services to their members but, just as importantly, they can help advance scholarly discussion with those practitioners creating global policy or transnationally implementing such designs.

Global actors engage HEIs in other ways. For example, professional staff of IOs are often adjunct faculty with universities. This is noticeable in Washington, DC, where many professional staff of the IMF and World Bank contribute to teaching at local universities. The UN has also created the United Nations University, headquartered in Tokyo, with UN Institutes worldwide. Many UN Institutes interface with graduate teaching programs in local partner universities. Through its Belgian arm, for instance, the Institute for Comparative Regional Integration Studies (UNU-CRIS) provides a considerable amount of research on global and regional policymaking that has double utility for teaching many of the European Commission's early career civil servants at the College of Europe, directly adjacent. More generally, the OECD and the Bretton Woods organizations have become "parts of overlapping sets of loose international networks... promoting the spread of best practices in public administration through capacity building projects in both government and academe" (Pal and Clark, 2016: 288). Unsurprisingly, IOs cultivate networks and training programs that accord with their organizational mission.

Philanthropic foundations are important professional partners. For instance, in 1993, the Ford and Macarthur Foundations jointly launched a multi-year project on globalization. More recently witnessed is foundation support for research and teaching on international development issues such as the Sustainable Development Goals (Verger et al, 2016) or the Gates Foundation's role in 'global health policy' (Carmen Huckel Schneider in Stone and Moloney, 2019). Others include the Welcome Trust, the Sasakawa Foundation, the Aga Khan Foundation, and the Open Society Foundations network. All are significant supporters of research programs or scholarship schemes. Over the past few decades, strategic grant making has brought a greater inclination on the part of philanthro-capitalists to influence policy, including global policies, through their financial support. The close connection of the Open Society Foundation network with the Central European University, both of which are endowed by the billionaire George Soros, exemplifies this trend. One risk of such grant-making is the criticism that such efforts create an elite cadre who conform to "the ideology of globalization ... and tends to be compliant with its requisites", with the university purposefully "training the administrators of globalization" (Guilhot 2007, p.449). That is, GP\&TA research and degree programs provide an educational service of 'interoperability' for "transnational public administration and global policy making... This is not a matter of speaking the same language (usually English) in a linguistic 
sense, but of being able to speak the same language in a conceptual sense" (our emphasis, Pal and Clarke, 2016, p.5).

\section{Conclusion}

This paper for the IRPP Forum has argued that there is an impoverished understanding of 'global governance' due to the paucity of scholarly analysis developing the conceptual categories of global policy and transnational administration. The reticence of mainstream policy, especially public administration scholars, to deploy their theoretical tool-kit to address global governance as being central rather than alien to their purview has been to the detriment of not only scholarship but also broader learning practices. Tendencies to methodological nationalism are deeply embedded in the study of public policy and public administration, albeit possibly more so among older generations than recent doctoral graduates. We suggest such tendencies insufficiently prepare scholars and their students to engage global policy actors, to understand the causes and consequences of transnational problems on states, and to reflect upon how a weakening administrative sovereignty reframes what is (or is not) administratively possible in global policy spaces. But conferences are one forum to foster new research themes. If the proportion of panels with a transnational or international policy focus at its 2019 biennial conference may signify, an international association like IPPA may well provide a nest for this scholarship. In the long run, however, we foresee that the study of GP\&TA has a rosy future as cross-border policy problems are growing, morphing and will remain a 'wicked' reality for both domestic and global policy makers alike.

Even so, we see several problematic issues in the study of GP\&TA of a cognitive, cultural, financial, and linguistic nature. Cognitively, the nation-state is the default unit of analysis in global governance studies. For most everyday people engaging with public policy, the nation-state is the primary actor and cognitive target for their citizenship orientation. It is a 'conceptual comfort-zone' in which methodological nationalism is upheld as the primary, or most appropriate, policy and administrative foci.

Culturally, in the post-Global Financial Crisis era of austerity politics, the rise of populist movements and nationalist policy-making is a political constraint on GP\&TA. This includes popular concerns about transnationally connected global elites who are largely shorn of any loyalty to a particular citizenship and who seek tax or other investment benefits without much consideration of local citizenry or global welfare (Piketty, 2014). From this vantage, the very notion of global policy or transnational administration becomes contested as an idea and is oftentimes resisted as a set of elite policy projects.

Universities, scholars and publishers are also under fiscal pressure, a pressure that may heighten tendencies to maintain mainstream approaches to policy studies or the teaching of public administration. More generally, these pressures have led to an 'adjunctification' of the professoriate, where research can sometimes be de-emphasized in favor of teaching, and where teaching gravitates to a methodologically national(ist) canon. Another consideration is a possible propensity for false advertising in HEIs: it is easy to slap on the phrase 'global policy of ...' or the 'transnational administration of ...' onto degree programs or scholarship when, in reality, minor tinkering or a re-branding ('old wine in a new bottle') has taken place.

A related issue concerns Western-dominance of what comes to be considered superior 'learning styles' and 'educational settings' (Xue, 2019; see also Gallagher et al, 2016). This is particularly significant when GP\&TA is undertaken via Western analytical lenses. This includes the dominance of English not just in the academic literature but also in the documents and projects of 
IOs, civil society, and other global governance actors. It is also the wealthier states and more mature HEIs - usually from OECD countries - that 'export' their educational models or determine that which becomes 'best practice' in pedagogy. While international collaboration in research or scholarship schemes are often designed for both inter-cultural exchange and academic learning, these schemes can also be regarded as a mechanism of 'soft power' and the spread of a hegemonic ideology. The study of GP\&TA is no less innocent in such narratives of power.

The challenge for public policy and public administration is evident. Cleaving to methodological nationalism has hampered disciplinary understanding of the changing world of policy and administration. Weakened or re-engineered administrative sovereignty, an increased number of non-state global (and regional) governance actors, new policy tools and networked administrative architectures, alongside expanding pressures to solve global and regional collective action problems requires increased disciplinary engagement with global policy and its transnational administration.

\section{Bibliography}

Anderson, L. (2019). The Future of the Public Policy School in a World of Disruptive Innovation. Global Policy, 10(1), 84-85.

Andersson K.P \& Ostrom E. (2008). Analyzing decentralized resource regimes from a polycentric perspective. Policy Sciences, 41(1), 71-93.

Andonova L.B. (2017). Governance entrepreneurs: international organizations and the rise of global public-private partnerships. Cambridge: Cambridge University Press.

Artaraz K. \& Hill M. (2016). Global Social Policy: Themes, Issues and Actors. London: Palgrave.

Bauer, M.W. \& Trondal, J. (eds.) (2015). The Palgrave Handbook of the European Administrative System. London/New York: Palgrave Macmillan.

Bauer M.W, Ege J. \& Schomaker R. (2018). The Challenge of Administrative Internationalization: Taking Stock and Looking Ahead, International Journal of Public Administration, https://doi.org/10. 1080/01900692.2018.1522642

Betsill M.M. \& Bulkeley, H. (2006). Cities and the Multilevel Governance of Global Climate Change. Global Governance: A Review of Multilateralism and International Organizations, 12(2), 141-159.

Bushouse B.K, Jacobson WS, Lambright, KT, et al. (2011). Crossing the Divide: Building Bridges Between Public Administration Practitioners and Scholars. Journal of Public Administration Research and Theory, 21(supplement1), i99-i112

Cooper T.L \& Yoder D.E (1999). The Meaning and Significance of Citizenship in a Transnational World: Implications for Public Administration. Administrative Theory \& Praxis, 21(2), 195-204.

Davies L. (2006). Global citizenship: abstraction or framework for action? Educational Review, 58(1), 5-25.

Deacon B. (2007). Global Social Policy and Governance. New York: Sage.

Dower N. \& Williams J. (2016). Global citizenship: A critical introduction. London: Routledge.

Drechsler W. (2013). Three paradigms of governance and administration: Chinese, Western, and Islamic. Society and Economy, 35(3), 319-342.

Farazmand A. (1999). Globalization and Public Administration. Public Administration Review, 59(6), 509-522. 
Flake L.G \& Snyder S. (eds) (2003). Paved with Good Intentions: The NGO Experience in North Korea. Westport: Praeger.

Gallagher J., Death C., Sabaratnam M, and Smith K (2016). Teaching Africa and international studies: Forum introduction. Politics, 36(4), 441-452.

Garsten C. \& Sörbom A. (2018). Discreet Power: How the World Economic Forum Shapes Market Agendas. Los Angeles: Stanford University Press.

Gehring T. \& Ruffing E. (2008). When arguments prevail over power: the CITES procedure for the listing of endangered species. Global Environmental Politics,8(2), 123-148.

GPPN (Global Public Policy Network) (n.d.) Global Public Policy Network [online]. Retrived from https://www.gppnetwork.org/about

Goren H. \& Yemini M. (2017). Global Citizenship Education Redefined - A Systematic Review of Empirical Studies on Global Citizenship Education. International Journal of Educational Research, 82, 170-183.

Guilhot N. (2007). Reforming the World: George Soros, Global Capitalism and the Philanthropic Management of the Social Sciences. Critical Sociology, 33(3), 447-477.

Hale T. \& Held D. (eds.) (2011). Handbook of Transnational Governance: Institutions and Innovations. Polity Press.

Haruna P.F. \& Kannae L.A. (2013). Connecting Good Governance Principles to the Public Affairs Curriculum: The Case of Ghana Institute of Management and Public Administration. Journal of Public Affairs Education, 19(3), 493-514.

Hirschman, A.O. (1981). Essays in trespassing: Economics to politics and beyond. CUP Archive.

Hou Y., Ni A.Y, Poocharoen O., Yang K., and Zhao Z.J. (2011). The Case for Global Administration with a Global Perspective, Journal of Public Administration Research and Theory, 21(Supplement1).

Hur Y. and Hackbart M. (2009). MPA vs MPP: A Distinction Without a Difference? Journal of Public Affairs Education, 15(4), 397-424.

Jamieson P., Dane J., \& Lippman P. (2005) Moving Beyond the Classroom: Accommodating the Changing Pedagogy of Higher Education. In: Refereed Forum Proceedings of the Australian Association for Institutional Research, Melbourne, Australia, 23-25 November,pp.17-23.

Jeong B. \& Kim P.S. (2019). Filling the Gap: Global Masters of Public Administration and Public Policy Programs. In: Stone D and Moloney K. (eds) The Oxford Handbook of Global Policy and Transnational Administration. Oxford: Oxford University Press, 346-363.

Kerler M. (2007). Triggering World Bank Reform: When Member States, NGOs and Learning Get Important. In: Bauer M. and Knill C. (eds), Management Reforms in International Organizations. Auflage: Nomos, 133-146.

Kennett P. (Ed.) (2008). Governance, Globalization and Public Policy. Cheltenham: Edward Elgar.

Kingsbury B., Krisch N., Stewart R.B. \& Wiener J.B. (2005). Foreword: Global governance as Administration--National and Transnational Approaches to Global Administrative Law. Law and Contemporary Problems, 68(3-4), 1-14.

Knill C., Bauer M.W., Eckhard S. (eds.) (2017). International Bureaucracy: Challenges and Lessons for Public Administration Research. London: Palgrave Macmillan.

Koppell J.G.S (2005). Pathologies of Accountability: ICANN and the Challenge of 'Multiple Accountabilities Disorder'. Public Administration Review, 65(1), 94-108.

Legrand T. (2019). Sovereignty Renewed: Transgovernmental Policy Networks and the Global-Local 
Dilemma. In: Stone D, Moloney K. (eds), Oxford Handbook of Global Policy and Transnational Administration. Oxford: Oxford University Press, 200-222.

Legrand T. \& Stone D. (2018). Science Diplomacy and Transnational Governance Impact. British Politics, 13(3), 392-408.

Manoharan A.P., Mirbel W., Carrizales T.J. (2018). Global Comparative Public Administration: Are Graduate Programs Responding to the Call? Teaching Public Administration, 36(1), 34-49.

Menzel D.C. \& White H.L. (eds.). (2011). The State of Public Administration: Issues, Challenges, and Opportunities. ME Sharpe: Taylor \& Francis.

Moloney K. (2018). Hurdles to an Asian Century of Public Administration. In: Bice S., Poole A., Sullivan H. (eds), Public Policy in the 'Asian Century': Concepts, Cases and Futures. Basingstoke: Palgrave Macmillan, 267-292.

Moloney K. \& Stoycheva R. (2018). Partial Two-Way Mirror: International Organization Budget Transparency. Global Policy, 9(1), 26-40.

Moran M., Rein M. \& Goodin R.E. (eds) (2006). The Oxford Handbook of Public Policy. Oxford: Oxford University Press.

OECD (2017). OECD Global Network of Schools of Government [online]. Paris: OECD. Retrived from http://www.oecd.org/gov/global-network-schools-of-government.htm

Pal L.A. \& Clark I.D. (2016). Teaching Public Policy: Global Convergence or Difference? Policy and Society, 35(4), 283-297. https://doi.org/10.1016/j.polsoc.2016.11.006

Piketty T. (2014). Capital in the Twenty-First Century. Cambridge: Belknap Press.

Stone D. \& Ladi S. (2015). Global Public Policy and Transnational Administration. Public Administration, 93(3), 839-55.

Stone D. \& Moloney K. (Eds.) (2019). Oxford Handbook of Global Policy and Transnational Administration, Oxford: Oxford University Press.

Szostak R. (2005). Interdisciplinarity and the Teaching of Public Policy. Journal of Policy Analysis and Management, 24(4), 853-863.

Turner B.S. (1993). Outline of a Theory of Human Rights. In: BS Turner (Ed.) Citizenship and Social Theory. London: Sage, 162-190.

Vabulas, F. (2019). The Importance of Informal Intergovernmental Organizations. In: Stone D, Moloney K (eds), Oxford Handbook of Global Policy and Transnational Administration. Oxford: Oxford University Press, 401-418.

Verger A., Lubienski C., \& Steiner-Khamsi G. (eds) (2016). World Yearbook of Education 2016: The global education industry. Abingdon: Routledge.

Volpe G. (2015). Case Teaching in Economics: History, Practice and Evidence. Cogent Economics \& Finance, 3(1), 1-18.

Walker C. (2009). Teaching Policy Theory and its Application to Practice Using Long Structured Case Studies: An Approach that Deeply Engages Undergraduate Students. International Journal of Teaching and Learning in Higher Education, 20(2), 214-225.

Wu X. \& He, J. (2009). Paradigm Shift in Public Administration: Implications for teaching in Professional Training Programs. Public Administration Review, 69(supplement1),

Xue, L. (2019). On the Future of Public Policy Schools, in Developing Countries. Global Policy, 10(1), 102-103. 